\title{
Analisis Kompetensi Petani Pepaya California (Studi Kasus Kelompok Tani Merta Giri Kusuma \\ Desa Abang, Kecamatan Abang, Kabupaten Karangasem)
}

\author{
I GEDE ARTHA SUDIARSANA, DWI PUTRA DARMAWAN, \\ I DEWA GEDE RAKA SARJANA
}

Program Studi Agribisnis Fakultas Pertanian Universitas Udayana

J1. PB. Sudirman Denpasar 80232

Email: arthasudiarsana@gmail.com

dwiputradarmawan@yahoo.com

\section{Abstract \\ Competence Analysis of California Papaya Farmers (A Case Study of Merta Giri Kusuma Farmer Group of Abang Village, Abang Sub-District of Karangasem Regency)}

The Ministry of Agriculture in the Strategic Plan 2015-2019 has a Gross Domestic Product target of $3.80 \%$ growth in the agricultural sector. Increased farm productivity is realized in the optimal utilization of land potential by applying the concept of agribusiness maximally. Efforts to increase productivity are conducted by increasing the competence of farmers namely knowledge, technical and managerial competence. The purpose of the study is to determine the level of competence of farmers, the level of productivity of California papaya farming, and the relationship between competence with productivity of California papaya farming. The research was conducted at Merta Giri Kusuma Farmer Group, Abang Village, Abang Sub-District, Karangasem Regency for 5 months. There are 20 members as population or the respondents taken by the census technique. Data analysis method used qualitative descriptive analysis and Rank Spearman correlation statistical analysis. In general, the competence of farmers is very significant ly related to the productivity of California papaya farming. A very real relationship at the 0.01 level is technical competence with a correlation coefficient of 0.835 and managerial competence with a correlation coefficient of 0,599 . While the competence that is significantly related to the productivity of farming at the 0.05 level is the knowledge competence with the correlation coefficient of 0.465 .

Keywords: california papaya farmers, competence, productivity, farmer group

\section{Pendahuluan}

\subsection{Latar Belakang}

Kementerian Pertanian dalam Rencana Strategis tahun 2015-2019 memiliki target Pendapatan Domestik Bruto sektor pertanian tumbuh 3,80\%. Pembangunan pertanian diarahkan untuk meningkatkan pendapatan dan taraf hidup petani, 
memperluas lapangan pekerjaan, dan mengisi serta memperluas pasar, baik pasar lokal maupun internasional. Peningkatan pendapatan petani dapat dilakukan dengan peningkatan produktivitas usahatani melalui pemanfaatan potensi lahan secara optimal. Upaya yang dilakukan untuk melakukan peningkatan produktivitas usahatani salah satunya dengan cara meningkatkan kompetensi petani.

Petani perlu memiliki kompetensi yang memadai agar dapat mengelola usahataninya dengan baik. Kompetensi petani dibagi menjadi beberapa elemen yakni, kompetensi pengetahuan, kompetensi teknis, serta kompetensi manajerial. Ketiga kompetensi tersebut apabila diimplementasikan dan dikuasai oleh petani Pepaya California, maka akan dapat mempengaruhi kinerja petani. Kinerja petani dapat dilihat dari produktivitas yang dicerminkan oleh kapasitas produksi petani. Kapasitas produksi yang kuantitasnya semakin banyak dengan kualitas hasil produksi yang baik, dapat mencerminkan bahwa kompetensi yang dimiliki petani adalah baik sehingga mampu memanfaatkan faktor produksinya dengan baik pula.

Berdasarkan hasil uraian di atas, dapat dilihat bahwa kompetensi petani memiliki korelasi pada produktivitas, sehingga peneliti tertarik untuk meneliti tingkat kompetensi petani Pepaya California dan hubungan kompetensi petani dengan produktivitas usahatani Pepaya California di Kelompok Tani Merta Giri Kusuma. Dapat dijadikan sebagai dasar dalam pengembangan kompetensi petani Pepaya California.

\subsection{Tujuan Penelitian}

Tujuan penelitian ini adalah mengidentifikasi tingkat kompetensi petani Pepaya California, melihat tingkat produktivitas usahatani Pepaya California dan keeratan hubungan antara kompetensi petani dengan produktivitas usahatani Pepaya California di Kelompok Tani Merta Giri Kusuma, Desa Abang, Kecamatan Abang, Kabupaten Karangasem

\section{Metode Penelitian}

\subsection{Lokasi dan Waktu Penelitian}

Penelitian ini dilakukan terhadap komunitas petani Pepaya California yang tergabung dalam Kelompok Tani Merta Giri Kusuma Desa Abang, Kecamatan Abang, Kabupaten Karangasem, Provinsi Bali. Penelitian ini dilaksanakan pada bulan November 2016 sampai dengan April 2017.

\subsection{Data dan Pengumpulan Data}

Jenis data yang digunakan yakni data kuantitatif yang mencakup jumlah produksi Pepaya California. Selain itu data kuantitatif diperoleh dari skor yang didapat dari kuesioner yang menggunakan skala likert. Data kualitatif ini mencakup kompetensi petani Pepaya California yang terdiri dari kompetensi pengetahuan, kompetensi teknis dan kompetensi manajerial serta gambaran umum Kelompok Tani Merta Giri Kusuma. Sumber data penelitian ini adalah sumber data primer dan 
sumber data sekunder. Adapun metode pengumpulan data yang digunakan adalah wawancara dengan instrument penelitian berupa kuesioener dan observasi.

\subsection{Penentuan Sampel Penelitian}

Penentuan sampel yang digunakan pada penelitian ini adalah metode nonprobability sampling dengan teknik sampel jenuh atau sensus dimana terdapat 20 orang anggota Kelompok Tani Merta Giri Kusuma sebagai populasi dan seluruhnya digunakan sebagai responden. Kelebihan dari metode ini terhadap penelitian adalah dapat menggambarkan keseluruhan anggota populasi yang diteliti (Sugiyono,2009).

\subsection{Variabel Penelitian}

Variabel yang digunakan dalam penelitian ini yaitu pengetahuan mengenai varietas tanaman, jenis bunga, jenis benih, musim tanam, jarak tanam (indikator kompetensi pengetahuan), persiapan lahan, persemaian, penanaman, pemeliharaan, panen dan pasca panen (indikator kompetensi teknis), membuat rencana usahatani, mencari modal usahatani, memasarkan hasil, kombinasi cabang usahatani, kerjasama kelembagaan (indikator kompetensi manajerial) dan produktivitas.

\subsection{Batasan Operasional Variabel}

Kompetensi petani Pepaya California adalah kemampuan petani dalam mengelola usahatani Pepaya California. Aspek pengetahuan terdiri dari: (pengetahuan mengenai jenis benih, jenis bunga, varietas tanaman, musim tanam dan jarak tanam). Aspek teknis yang terdiri dari: (penyiapan lahan, persemaian benih, penanaman, pemeliharaan dan panen dan pasca panen). Aspek manajerial yang terdiri dari: (membuat rencana usahatani, mencari modal usahatani, memasarkan hasil, kombinasi cabang usahatani dan kerjasama kelembagaan). Produktivitas merupakan tingkat produksi per hektar (ton/ha).

\subsection{Analisis Data}

Data yang diperoleh diolah melalui proses editing, coding, scoring, entry data, cleaning data, dan analisis data. Penilaian terhadap data kompetensi yaitu semakin tinggi persentase dari skor yang diperoleh maka semakin baik kompetensinya. Sama halnya dengan data produktivitas usahatani dimana persentase yang semakin tinggi akan semakin positif nilai produktivitas usahatani tersebut.

Pengujian instrumen dilakukan untuk menguji apakah instrumen penelitian berupa jawaban dari responden sudah dijawab dengan benar atau tidak dengan menggunakan uji validitas dan reliabilitas. Analisis data yang digunakan adalah analisis data deskriptif dan analisis korelasi rank spearman. Analisis data deskriptif digunakan untuk menjabarkan secara jelas dan sistematis suatu data agar memperoleh gambaran kompleks dengan mecermati tanggapan responden (Wibowo, 2011). Skor rataan digunakan untuk mengelompokkan jawaban responden terhadap masing-masing kriteria pada skala likert (skala 1 s/d 5). Responden 
dikelompokkan didalam setiap kriteria lalu dikalikan dengan bobotnya, dan hasil perkalian di dalam setiap kriteria dijumlahkan kemudian dibagi dengan jumlah respondennya, sehingga diperoleh suatu nilai skor rataan yang berada pada skala 1 s/d 5 (Umar, 2003).

Analisis korelasi rank spearman digunakan untuk mencari hubungan atau menguji signifikansi hipotesis asosiatif bila masing-masing variabel yang dihubungkan berbentuk ordinal, dan sumber data antara variabel tidak harus sama (Sugiyono, 2014). Pengujian hipotesis dengan menggunakan analisis uji rank spearman pada $\alpha=0,05$ atau $\alpha=0,01$ (Siegel,1992), dan pengolahan data menggunakan program SPSS (Statistic Package of Social Sciene) versi 21.

\section{Hasil dan Pembahasan}

\subsection{Karakteristik Responden}

Berdasarkan hasil penelitian dari total 20 orang responden rata-rata umur responden adalah 40,65 tahun dan mayoritas (50\%) petani Pepaya California berumur muda kurang dari 40 tahun. Tingkat pendidikan responden mayoritas (75\%) berpendidikan rendah atau tamatan SD dan tidak bersekolah. Kepemilikan lahan petani Pepaya California mayoritas (80\%) memiliki lahan sedang (0,1 - 0,2 ha). Pengalaman berusahatani Pepaya California sebesar mayoritas, sebanyak 50\% petani memiliki pengalaman yang cukup ( tiga sampai empat tahun).

\subsection{Tingkat Kompetensi Petani Pepaya California}

\subsubsection{Kompetensi pengetahuan}

Terdapat lima bidang kognitif yang diukur dalam penelitian ini, yaitu pengetahuan dalam hal: varietas tanaman, jenis benih, jenis bunga, musim tanam dan jarak tanam. Pengetahuan petani dalam berusahatani Pepaya California disajikan pada Tabel 1.

Tabel 1.

Skor Kompetensi Pengetahuan Responden

\begin{tabular}{|c|c|c|}
\hline Variabel & Skor Rataan & Kategori \\
\hline Varietas tanaman & 4,10 & Memadai \\
\hline Jenis benih & 3,95 & Memadai \\
\hline Jenis bunga & 3,90 & Memadai \\
\hline Musim tanam & 3,90 & Memadai \\
\hline Jarak tanam & 4,10 & Memadai \\
\hline Rata-rata & 3,99 & Memadai \\
\hline
\end{tabular}

Berdasarkan hasil penelitian, kompetensi pengetahuan petani Pepaya California pada Kelompok Tani Merta Giri Kusuma berada dalam kategori memadai dengan rata-rata skor 3,99. Buah pepaya dari tanaman pepaya sempurna ini umumnya berdaging tebal dan berbiji banyak sekali. Tanaman pepaya dengan bunga betina, 
apabila menjadi buah akan berbentuk bulat, berdaging tipis dan biasanya bijinya sedikit. Tanaman pepaya dengan bunga jantan ini tidak enak dimakan, karena rasanya agak pahit (Sunaryono, 1989).

\subsubsection{Kompetensi teknis}

Dalam budidaya Pepaya California terdapat lima tahapan yaitu penyiapan lahan, persemaian, penanaman, pemeliharaan dan panen dan pasca panen. Kompetensi teknis petani Pepaya California disajikan pada Tabel 2.

Tabel 2.

Skor Kompetensi Teknis Responden

\begin{tabular}{lcl}
\hline \multicolumn{1}{c}{ Variabel } & Skor Rataan & \multicolumn{1}{c}{ Kategori } \\
\hline Persiapan lahan & 4,10 & Memadai \\
Persemaian & 4,10 & Memadai \\
Penanaman & 4,30 & Sangat memadai \\
Pemeliharaan & 4,15 & Memadai \\
Panen dan pasca panen & 4,30 & Sangat Memadai \\
\hline Rata-rata & 4,19 & Memadai \\
\hline
\end{tabular}

Berdasarkan hasil penelitian, kompetensi teknis petani Pepaya California pada Kelompok Tani Merta Giri Kusuma berada dalam kategori memadai dengan rata-rata skor 4,19 .

\subsubsection{Kompetensi Manajerial}

Pengelolaan usahatani (management) adalah kemampuan petani menentukan, mengorganisir dan mengkoordinasikan faktor-faktor produksi yang dikuasainya sebaik-baiknya, dan mampu memberikan produksi pertanian sebagaimana yang diharapkan (Hernanto, 1993). Terdapat lima bidang kompetensi manajerial yang diukur dalam penelitian ini yaitu membuat rencana usahatani, mencari modal usahatani, memasarkan hasil, kombinasi cabang usahatani dan kerjasama kelembagaan. Kompetensi manajerial petani Pepaya California disajikan pada Tabel 3.

Tabel 3.

Skor Kompetensi Manajerial Responden

\begin{tabular}{lcl}
\hline \multicolumn{1}{c}{ Variabel } & Skor Rataan & \multicolumn{1}{c}{ Kategori } \\
\hline Membuat rencana usahatani & 3,55 & Memadai \\
Mencari modal usahatani & 3,60 & Memadai \\
Memasarkan hasil & 3,40 & Cukup memadai \\
Kombinasi cabang usahatani & 2,75 & Cukup memadai \\
Kerjasama kelembagaan & 2,80 & Cukup memadai \\
\hline Rata-rata & 3,22 & Cukup memadai \\
\hline
\end{tabular}


Berdasarkan hasil penelitian, kompetensi manajerial petani Pepaya California pada Kelompok Tani Merta Giri Kusuma berada dalam kategori cukup memadai dengan rata-rata skor 3,22.

\subsection{Tingkat Produktivitas Usahatani Pepaya California}

Produktivitas mengandung pengertian perbandingan antara hasil yang dicapai dengan keseluruhan sumber daya yang digunakan (Krech et all dalam Husin, 2009). Hasil penelitian mengenai produktivitas usahatani Pepaya California tersebut dapat dilihat pada Tabel 4.

Tabel 4.

Distribusi Petani Pepaya California Menurut Produktivitas

\begin{tabular}{lcc}
\hline \multicolumn{1}{c}{ Produktivitas } & Jumlah & Persen $(\%)$ \\
\hline Sangat rendah $(8,25-9,4$ ton/ha) & 1 & $5 \%$ \\
Rendah $(9,4-10,55$ ton/ha) & 1 & $5 \%$ \\
Sedang $(10,55-11,7$ ton/ha) & 4 & $20 \%$ \\
Tinggi(11,7-12,85 ton/ha) & 9 & $45 \%$ \\
Sangat tinggi $(12,85-14$ ton/ha) & 5 & $25 \%$ \\
\hline Jumlah & 20 & $100 \%$ \\
\hline
\end{tabular}

Keterangan : Minimum : 8,25 ton/ha; Maksimum : 14 ton/ha

Rata-rata : 12,26 ton/ha

Tabel 4. diatas menunjukkan seperlima petani Pepaya California pada Kelompok Tani Merta Giri Kusuma memiliki produktivitas sedang dengan produktivitas 10,55-11,7 ton/ha, kurang dari setengah petani Pepaya California memiliki produktivitas yang tinggi dengan produktivitas 11,7-12,85 ton/ha, seperempat petani Pepaya California memiliki produktivitas yang sangat tinggi dengan produktivitas $12,85-14$ ton/ha, dan sisanya memiliki produktivitas rendah dan sangat rendah. Rata-rata kinerja petani tinggi dengan pencapaian skor sebesar 3,8.

\subsection{Hasil Analisis Korelasi Rank Spearman}

\subsubsection{Analisis hubungan kompetensi pengetahuan, kompetensi teknis, dan} kompetensi manajerial dengan produktivitas

Berdasarkan Tabel 5, hasil analisis korelasi antara variabel kompetensi pengetahuan dengan produktivitas adalah sebesar 0,465 dengan nilai $\mathrm{p}=0,039<$ nilai signifikansi $\alpha(0,05)$ sehingga keputusan $\mathrm{H}_{0}$ ditolak artinya $\mathrm{H}_{1}$ diterima. Hal ini menunjukkan bahwa terdapat hubungan yang nyata (kategori sedang) dan positif antara variabel kompetensi pengetahuan dengan produktivitas usahatani Pepaya California. 


\section{Tabel 5.}

Hasil Analisis Korelasi Kompetensi Pengetahuan, Kompetensi Teknis, dan Kompetensi Manajerial dengan Produktivitas

\begin{tabular}{llcc}
\hline \multirow{2}{*}{ No } & \multirow{2}{*}{ Kompetensi Petani } & \multicolumn{2}{c}{ Produktivitas } \\
\cline { 3 - 4 } & & Koefisien korelasi & $\mathrm{p}$ \\
\hline 1 & Pengetahuan & $0,465^{*}$ & 0,039 \\
2 & Teknis & $0,835^{* *}$ & 0,000 \\
3 & Manajerial & $0,599^{* *}$ & 0,005 \\
\hline
\end{tabular}

Keterangan tabel :

$\mathrm{n}=20$ orang; $\mathrm{p}=$ peluang kesalahan (galat)

** Berhubungan sangat nyata pada $\alpha=0,01$

* Berhubungan nyata pada $\alpha=0,05$

Pada variabel kompetensi teknis, hasil analisis korelasi untuk variabel kompetensi teknis dengan produktivitas adalah sebesar 0,835 dengan nilai $\mathrm{p}=0,000$ $<$ nilai signifikansi $\alpha(0,01)$ yang menunjukkan bahwa $\mathrm{H}_{0}$ ditolak artinya $\mathrm{H}_{1}$ diterima. Hal ini berarti terdapat hubungan antara variabel kompetensi teknis dengan produktivitas usahatani yang sangat nyata (kategori sangat kuat).

Pada variabel kompetensi manajerial, hasil analisis korelasi untuk variabel kompetensi manajerial dengan produktivitas adalah sebesar 0,599 dengan nilai $\mathrm{p}=$ $0,005<$ nilai signifikansi $\alpha(0,01)$ yang menunjukkan bahwa $\mathrm{H}_{0}$ ditolak artinya $\mathrm{H}_{1}$ diterima. Hal ini berarti bahwa terdapat hubungan antara variabel kompetensi manajerial dengan produktivitas usahatani Pepaya California yang berarti terdapat hubungan yang sangat nyata (kategori sedang) dan positif antara variabel kompetensi manajerial dengan produktivitas usahatani Pepaya California.

\subsubsection{Analisis hubungan kompetensi dengan produktivitas usahatani Pepaya California}

Berdasarkan Tabel 6 hasil yang diperoleh dari analisis uji korelasi rank spearman menunjukkan bahwa terdapat hubungan antara variabel kompetensi dengan produktivitas. Hasil korelasi untuk variabel kompetensi dengan produktivitas yang dihasilkan dari nilai korelasi rank Spearman adalah sebesar 0,663 dengan nilai $\mathrm{p}=$ $0,001<$ nilai signifikansi $\alpha(0,01)$. Hal ini berarti $\mathrm{H}_{0}$ ditolak dan $\mathrm{H}_{1}$ diterima yang berarti terdapat hubungan yang sangat nyata (kategori kuat) dan positif antara variabel kompetensi dengan produktivitas usahatani Pepaya California. 
Tabel 6.

Hasil Analisis Korelasi Variabel Kompetensi dengan Produktivitas

\begin{tabular}{lcc}
\hline Variabel & Kompetensi petani & Produktivitas \\
\hline Kompetensi petani (nilai korelasi) & - & $0,663^{* *}$ \\
\hline Produktivitas (nilai peluang) & 0.001 & - \\
\hline
\end{tabular}

Keterangan tabel :

** Berhubungan sangat nyata pada $\alpha=0,05$

* Berhubungan nyata pada $\alpha=0,05$

Petani di daerah studi yang mampu memproduksi Pepaya California dalam jumlah lebih dari petani lain, mempunyai pengetahuan dan kompetensi teknis yang tinggi dalam hal: pengetahuan mengenai varietas pepaya, jenis benih, jenis bunga, jarak tanam dan musim tanam yang tepat. Petani mampu dalam hal : melakukan pengolahan lahan, penyemaian benih, pengendalian hama penyakit dan mengidentifikasi ciri-ciri buah yang siap di panen. Pengetahuan dan kemampuan petani didapatkan dari belajar kepada sesama petani dari dalam dan luar sistem sosial. Pengetahuan dan kemampuan menjadi penentu keberhasilan produksi petani Pepaya California. Jadi kompetensi berkaitan erat dengan karakter dasar yang dimiliki oleh seseorang dan berhubungan erat dengan produktivitas usahatani efektif (Spencer and Spencer, 1993 dalam Manyamsari dan Mujiburrahmad, 2014).

Hasil penelitan ini meyakinkan bahwa petani Pepaya California dapat memiliki produktivitas yang lebih baik, jika petani memiliki kompetensi yang tinggi dan memadai yang meliputi kompetensi pengetahuan, teknis dan manajerial. Keadaan ini diharapkan dapat mendorong dilakukan pemberdayaan petani Pepaya California, yaitu upaya peningkatan kompetensi pengetahuan, teknis dan manajerial. Petani Pepaya California pada Kelompok Tani Merta Giri Kusuma membutuhkan dukungan dalam peningkatan kompetensinya guna peningkatan produksi, terutama dalam membangun kapasitas diri atau kemampuannya mengembangkan usahatani. Hal ini sejalan dengan pendapat Nuhung (2006), bahwa bantuan yang diberikan bagi petni seyogyanya yang memberdayakan kapasitas atau kemampuan produktif; artinya bantuan yang diberikan mampu menciptakan peluang kerja bagi petani, mampu membuat petani bekerja untuk memperoleh pendapatan dan menopang hidupnya secara berkelanjutan: dengan demikian "kemampuan produktifnya" sebagai manusia akan selalu terasah sebagai pelaku pembangunan.

\section{Kesimpulan dan Saran}

\subsection{Kesimpulan}

Kesimpulan yang dapat ditarik dari penelitian ini adalah sebagai berikut :

1. Tingkat kompetensi petani Pepaya California pada Kelompok Tani Merta Giri Kusuma yang terdiri dari : (1) kompetensi pengetahuan masuk dalam kategori memadai dengan skor 3,99, (2) kompetensi teknis masuk dalam kategori memadai 
dengan skor 4,19, dan (3) kompetensi manajerial yang masuk dalam kategori cukup memadai dengan skor 3,22.

2. Mayoritas tingkat produktivitas usahatani Pepaya California memiliki produktivitas usahatani yang tinggi dengan produktivitas sebesar 11,7-12,85 ton/ha per tahun dengan pencapaian skor sebesar 3,8.

3. Kompetensi petani memiliki hubungan sangat nyata dengan produktivitas usahatani Pepaya California dengan koefisien korelasi sebesar 0,663 pada taraf 0.01 . Hubungan yang sangat nyata pada taraf 0,01 adalah kompetensi teknis dengan koefisien korelasi sebesar 0,835 dan kompetensi manajerial dengan koefisien korelasi sebesar 0,599. Sedangkan kompetensi yang berhubungan nyata dengan produktivitas pada taraf 0,05 adalah kompetensi pengetahuan dengan koefesien korelasi sebesar 0,465.

\subsection{Saran}

1. Diperlukan upaya-upaya agar kompetensi yang masih kurang (lemah) seperti kompetensi manajerial dapat ditingkatkan melalui pendidikan non formal seperti penyuluhan dan pelatihan yang lebih intensif di lokasi penelitian.

2. Perlu dilakukan penelitian lebih lanjut terhadap beberapa komponen kompetensi lain, yang diduga berhubungan dengan produktivitas usahatani Pepaya California.

\section{Ucapan Terimakasih}

Ucapan terimakasih ini peneliti tujukan kepada seluruh pihak yang telah membantu dalam pelaksanaan penelitian hingga karya ilmiah ini bisa dipublikasikan dalam e-jurnal.

\section{Daftar Pustaka}

Kementerian Pertanian. 2015. Rencana Strategis Kementerian Pertanian Tahun 2015-2019. Jakarta

Hernanto, F. 1993. Ilmu Usahatani Jakarta (ID): Penebar Swadaya.

Husin, Sofyan. 2009. Analisis Faktor-Faktor yang Mempengaruhi Produktivitas Usahatani dan Pengaruhnya Terhadap Kepuasan Petani (Studi Kasus Bumdes PT Agropotombuluh di Kecamatan Telaga Biru Kabupaten Gorontalo (Tesis). Fakultas Ekonomi Program Magister Perencanaan dan Kebijakan Publik. Universitas Indonesia

Manyamsari, Ira dan Mujiburrahmad. 2014. Karakteristik Petani dan Hubungannya dengan Kompetensi Petani Lahan Sempit (Kasus: Di Desa Sinar Sari Kecamatan Dramaga Kab. Bogor Jawa Barat. E-Jurnal Agrisep Jurusan Sosial Ekonomi Pertanian Fakultas Pertanian Universitas Syiah Kuala Vol 15 No.2.

Nuhung, I.A. 2006. Bedah Terapi Pertanian Nasional : Peran Strategis dan Revitalisasi. Jakarta : PT. Bhuana Ilmu Populer

Siegel, S. 1992. Statistik Nonparametrik: untuk Ilmu-ilmu Sosial. Jakarta: PT. Gramedia Utama

Sugiyono. 2009. Metode Penelitian Kuantitatif, Kualitatif dan R\&D. Bandung: Alfabeta 
Sugiyono. 2014. Metode Penelitian Bisnis: Pendekatan Kuantitatif, Kualitatif, dan $R \& D$. Bandung: Alfabeta

Sunaryono, Hendro.1989. Pengenalan Jenis Tanaman Buah-Buahan \& Bercocok Tanam Buah-Buahan Penting di Indonesia. Bandung: Sinar Baru Bandung

Umar H. 2003. Metodologi Penelitian untuk Skripsi dan Thesis Bisnis. Jakarta (ID): PT Gramedia Pustaka

Wibowo. 2011. Manajemen Produktivitas usahatani. Jakarta: Rajawali Press. 